\title{
Altered Activity of Peroxidase and Oxalate Oxidase Influences Lignification in Transgenic Tobacco
}

\author{
Emma Burbridge $^{1, \mathrm{a}}$, Søren Kjærsgaard Rasmussen ${ }^{2}$, Francois Bernier ${ }^{3}$, Brian Kaare Kristensen ${ }^{2, \mathrm{~b}}$, \\ Paul Francis McCabe ${ }^{4}$ and Philip John Dix ${ }^{1, *}$
}

\author{
${ }^{I}$ Department of Biology, National University of Ireland Maynooth, Maynooth, Co. Kildare, Ireland; ${ }^{2}$ Department of \\ Plant and Environmental Sciences, University of Copenhagen, 1871 Frederiksberg, Denmark; ${ }^{3}$ Institut de Biologie \\ Moleculaire des Plantes, Institut de Botanique, Strasbourg, France; ${ }^{4}$ School of Biology and Environmental Science, \\ University College Dublin, Belfield, Dublin 4, Ireland
}

\begin{abstract}
Peroxidase and hydrogen peroxide both play important roles in the final stages of the lignification pathway. Peroxidase, in the presence of $\mathrm{H}_{2} \mathrm{O}_{2}$ catalyses the oxidation of monolignols to give lignin. In order to examine this process we looked at lignification in transgenic tobacco plants expressing a barley peroxidase gene, $H v \operatorname{Pr} x 8$, either alone or in combination with a wheat germin gene, $g . f 2.8$, which encodes oxalate oxidase, thereby providing a source of $\mathrm{H}_{2} \mathrm{O}_{2}$. Elevated activity of the antioxidant ascorbate peroxidase was found in plants expressing oxalate peroxidase and was greatly increased by co-expression with the barley peroxidase, although the latter had no effect when expressed alone. An increase was observed in the oxidation of the lignin monomer, syringaldazine in cell lines over-expressing barley peroxidase, while a decrease was observed in double transformants. Plants over-expressing barley peroxidase have elevated levels of lignin deposition compared to that of wild type tobacco plants. Over-expression of the individual enzymes was also shown to enhance heat-induced programmed cell death (PCD) in cell suspension cultures, an effect which was greatly reduced in the double-expressing lines.
\end{abstract}

Keywords: Lignin, oxalate oxidase, peroxidase, syringaldazine.

\section{INTRODUCTION}

Plant peroxidases (EC 1.11.1.7) are extremely well studied proteins. They are induced by biotic [1,2] and abiotic [3] stress and peroxidase is often the first enzyme to alter its activity after stimulation, irrespective of the stress applied [4]. Peroxidases also play a part in many physiological and biochemical plant processes, including the regulation of the level of auxin in early stages of differentiation [5], and lignification. In the latter process, peroxidase, in the presence of $\mathrm{H}_{2} \mathrm{O}_{2}$, catalyses the oxidation of monolignols to free radicals which polymerise to give lignin [6-8]. It has been demonstrated that altered peroxidase expression can have a dramatic effect on the physiology and morphology of plants. Examples include induced wilting, reduced root mass, changes in plant height, flowering time, axillary bud development and lignin content [9-11]. Peroxidases in plants are generally represented by numerous isoenzymes and can be encoded by a sizeable gene family, for example the Arabidopsis genome contains 73 class III peroxidase genes of which at least 53 are expressed [12]. It has however been difficult to assign specific functions to individual

\footnotetext{
*Address correspondence to this author at the Department of Biology, National University of Ireland Maynooth, Maynooth, Co. Kildare, Ireland;

Tel: +353 (0) 1 7083836; Fax: +353 (0) 1 7083845;

E-mail:phil.dix@nuim.ie

${ }^{a}$ Current Address: Instituto Gulbenkian de Ciência, Rua da Quinta Grande 6, 2780-156, Oeiras, Portugal

${ }^{b}$ Current Address: Novo Nordisk A/S, Novo Nordisk Park, DK-2760 Måløv,
} Denmark peroxidases due to a high redundancy factor found in peroxidase genes and the broad spectrum of substrates accepted by these enzymes. As has been observed [13] there seems to be no simple sequence similarity that allows the identification of lignin-related peroxidases across the plant kingdom.

The main function of cell wall targeted peroxidases has been shown [14] to be the oxidation of monolignols in the presence of hydrogen peroxide $\left(\mathrm{H}_{2} \mathrm{O}_{2}\right)$, while it has also been demonstrated [15] that free intercellular peroxidases are associated with xylem differentiation and lignification. Poplar peroxidases with the ability to oxidise syringaldazine - a lignin monomer analogue, have been characterised [16] showing that the activity of these enzymes correlated with lignifications, and over-expressing peroxidases in tobacco [9] and tomato [8] significantly increased the lignin content in transgenic plants. A pathogen-inducible barley peroxidase gene $\operatorname{pr} x 8$ is closely associated with the hypersensitive response [17] and the associated ROS-induced cell death. As cell death is frequently observed feature of the differentiation of the lignified cells of the vascular tissue, this gene was a promising candidate for exploration in transgenic plants.

Another oxidative enzyme implicated in stress responses is oxalate oxidase (germin). The wheat gene for this enzyme has been transformed into tobacco [18] resulting in plants in which a range of stressing agents induced elevated oxalate oxidase activity [19] suggesting that germin plays a role in plant stress responses. Increased oxalate oxidase activity has also been found in response to salt stress [20] and fungal 
infection [21]. This increased activity can result in sustained $\mathrm{H}_{2} \mathrm{O}_{2}$ production (as opposed to an oxidative burst) [22]. In view of the key role of $\mathrm{H}_{2} \mathrm{O}_{2}$ in lignification, we hypothesised that over-expression of oxalate oxidase genes, alone or in combination with peroxidase could influence the process of lignification.

In modifying $\mathrm{H}_{2} \mathrm{O}_{2}$ levels with a view to exploring lignin metabolism, one needs to be aware of the possible consequences resulting from concomitant elevation of other ROS, including superoxide $\left(\mathrm{O}_{2}{ }^{-}\right)$and the hydroxyl radical $\left({ }^{\circ} \mathrm{OH}\right)$. To counteract excessive levels of these potentially lethal ROS a battery of antioxidant defences has evolved [23-25]. We have recently demonstrated that elevated levels of some of these enzymes (superoxide dismutase, dehydroascorbate reductase, glutathione reductase, and glutathione-Stransferase) in chloroplasts influence redox cycling of antioxidants glutathione and ascorbate, leading to a modified response to abiotic stresses [26, 27]. The antioxidant ascorbate peroxidase examined in the current work (APX, EC 1.11.1.11) is found in nearly all cellular compartments, including the apoplast, cytosol, vacuole, chloroplast and mitochondrion [25].

Lignification is associated with tracheary element (TE) programmed cell death (PCD), but is a distinct process that can occur even after TE differentiation and death. PCD is a controlled process, under genetic regulation, leading to the organised breakdown of the cell. It occurs in normal development and in response to environmental cues. TE differentiation does not have all the hallmarks of plant PCD, it does exhibit vacuole collapse [28] and detectable DNA fragmentation [29]. We wished to investigate if our findings on lignification correlate with cell death rates. A cell morphology assay devised to measure cell death in response to heat treatment [30] has been applied to determine the influence of introduced peroxidase genes on rates of cell death [31]. The same approach has been used to explore the combined effects of peroxidase and oxalate oxidase gene expression in the current study.

\section{MATERIALS AND METHODS}

\section{Plant Material and Culture Conditions}

Tobacco (Nicotiana tabacum L. cv. Xanthi) shoot cultures were maintained on MS medium [32] at $25^{\circ} \mathrm{C}$ under a 16/8-hour light/dark photoperiod and sub-cultured as nodal cuttings every 4-6 weeks. Nicotiana tabacum L. cv. Xanthi (Xan nc5) seeds transformed with the oxalate oxidase gene, $g f-2.8$ [18] were surface sterilised for $10 \mathrm{~min}$ in $10 \% \mathrm{com}$ mercial bleach ("Domestos"), washed three times in sterile distilled water, and germinated on half-strength MS medium, supplemented with $100 \mathrm{mg} \mathrm{l}^{-1}$ kanamycin sulphate.

In order to establish cell suspension cultures, leaf strips cut from axenic leaves were transferred to MS medium containing $2 \mathrm{mg} \mathrm{l}^{-1} \mathrm{NAA}$ and $0.25 \mathrm{mg}^{-1}$ kinetin to induce the production of callus. Cell suspension cultures were established by inoculating friable callus into $50 \mathrm{ml}$ liquid culture medium (MS medium supplemented with $0.1 \mathrm{mg} \mathrm{l}^{-1}, 2,4-\mathrm{D}$ and $0.1 \mathrm{mg} \mathrm{l}^{-1}$ Kinetin) in $250 \mathrm{ml}$ conical flasks with , and incubating on a rotary shaker, at $25^{\circ} \mathrm{C}$. Cultures were subcultured by transferring $10 \mathrm{ml}$ to fresh medium every 10 days.

\section{Vector Construction and Transformation}

All plasmid DNA for restriction digests, PCR and sequencing was isolated using Wizard ${ }^{\circledR}$ Plus Minipreps or Midipreps DNA purification systems (Promega), according to the manufacturers instructions. The barley peroxidase coding sequence was cloned into a BAR-containing Ti-plasmid, as described previously [31]. A $1.2 \mathrm{~kb} P s t \mathrm{I} / \mathrm{SphI}$ fragment of the cDNA clone, pBH-301 [17] was cloned into the PstI and $S p h I$ sites on a pPS48 vector derived from pBI121 (Clontech), which provided the enhanced cauliflower mosaic virus (CaMV) $35 \mathrm{~S}$ promoter and terminator. A resulting $2.2 \mathrm{~kb}$ HindIII fragment was then isolated and cloned into the Hin$d$ III site of the Ti-plasmid CAMBIA 3301, containing the Basta selection gene and the $\beta$-glucuronidase (GUS) reporter gene, under the control of the CaMV-35S promoter. A positive clone was transformed into Escherichia coli (DH5 $\alpha$ ) using kanamycin as a selection pressure and positive clones were identified by PCR using the following primers: TDT15 [AACAGTCGTGGAAGTGCAGC] and $35 \mathrm{~S}$ reverse [ACTGACGTAAGGGATGACGC]. Clones were also checked by sequencing using a DNA sequencer model ABI 373, Perkin-Elmer. The construct was transformed into the supervirulent Agrobacterium tumefaciens strain C58C1using a freeze-thaw method, as described previously [31].

That report also describes in detail the production and characterisation of transgenic plants of $N$. tabacum L. cv. Xanthi, containing the barley peroxidase gene, $H v \operatorname{Pr} x 8$. The same vector and transformation procedure were used to transform N. tabacum L. cv. Xanthi (Xan nc5), the transgenic line expressing the oxalate oxidase gene [18] to obtain doubly transformed shoots. After rooting, PCR was used to screen for the presence of the HvPrx 8 using the primers described above. Positive plants exhibited amplification of a 356 bp product.

\section{Protein Extraction and Peroxidase Activity Assay}

Leaf material was homogenised in extraction buffer, (50 mM sodium phosphate, $\mathrm{pH} 6.2 ; 100 \mathrm{mg} / \mathrm{ml}$ tissue/buffervolume ratio), and the crude extract centrifuged at $16,000 \mathrm{~g}$ for $10 \mathrm{~min}$. Total soluble protein in the supernatant was quantified according to Bradford [33] using BSA as standard protein. Peroxidase activity was determined by adding 1-20 $\mu$ l supernatant to $1 \mathrm{ml}$ reaction mixture $(0.28 \%$ guaiacol and $0.30 \% \mathrm{H}_{2} \mathrm{O}_{2}$ in $0.05 \mathrm{M} \mathrm{Na}_{2} \mathrm{HPO}_{4}, \mathrm{pH} 6.2$ ) and measuring the increase in absorbance for $3 \mathrm{~min}$ at 30 second intervals at $420 \mathrm{~nm}$.

\section{Cellular Fractionation}

A modified form of the method of McDougall [34] was used. For leaf material, $10 \times 1 \mathrm{~cm}$ diameter discs were cut with a cork borer, weighed and washed in sterile water. For cell suspension cultures, cells were filtered and a known weight of cells used. Samples were immersed in $5 \mathrm{ml}$ sterile water and vacuum infiltrated at $15 \mathrm{~mm} \mathrm{Hg}$ for 5 minutes, before being dabbed dry on sterile filter paper. They were then transferred to $5 \mathrm{ml}$ syringe barrels, inserted into $30 \mathrm{ml}$ universals, and centrifuged at 1,500 g for $15 \mathrm{~min}$. The infiltrate was used to determine the soluble enzyme activity in the apoplast. To determine the combined soluble and ionically bound enzyme activity in the apoplast, the procedure 
was repeated with additional leaf discs immersed in $10 \mathrm{mM}$ $\mathrm{CaCl}_{2}$. The residual leaf material from this extraction was ground in liquid nitrogen containing $5 \mathrm{ml}$ buffer $(10 \mathrm{mM}$ sodium phosphate, $\mathrm{pH}$ 7.2). The homogenate was centrifuged at $16,000 \mathrm{~g}$ and the supernatant was used to determine cytosolic and vacuolar activity. The pellet was transferred to $1 \mathrm{~g}$ Cellulase and $600 \mathrm{mg}$ Macerozyme (Sigma) in $100 \mathrm{ml}$ of the same buffer, incubated overnight at $25^{\circ} \mathrm{C}$ before centrifugation at $16,000 \mathrm{~g}$. The supernatant was used to determine cell wall bound activity.

\section{Ascorbate Peroxidase Assay}

A method from Asada [35] was modified as follows. Leaf tissue $(0.3 \mathrm{~g})$ was ground in liquid nitrogen and $10 \mathrm{ml}$ of extraction buffer (50 mM sodium phosphate, $\mathrm{pH} 7.0$, $1 \mathrm{mM}$ ascorbic acid, $1 \mathrm{mM}$ EDTA, 1\% Triton X-100 and $1 \%$ PVP) was added. Once thawed the extract was transferred to a $15 \mathrm{ml}$ tube, vortexed and spun at $800 \mathrm{~g}$ for $15 \mathrm{~min}$ at $4^{\circ} \mathrm{C}$. Ascorbate peroxidase activity of the supernatant was determined by adding it to the reaction mixture $(50 \mathrm{mM}$ sodium phosphate buffer, $\mathrm{pH} 7.0,100 \mathrm{mM} \mathrm{H}_{2} \mathrm{O}_{2}$ ) to a final concentration $10 \mu \mathrm{l}$ of $50 \mathrm{mM}$ of $1 \%$. The increase in absorbance at $290 \mathrm{~nm}$ was read over a period of 3 minutes after the addition of $10 \mu 1$ of $50 \mathrm{mM}$ ascorbate.

\section{Oxidation of Syringaldazine}

This assay was carried out on apoplastic fluid. $10 \times 1 \mathrm{~cm}$ diameter leaf discs were cut with a cork borer, immersed in $5 \mathrm{ml}$ sterile water and vacuum infiltrated for $5 \mathrm{~min}$ at $15 \mathrm{~mm}$ $\mathrm{Hg}$. They were then left to stand for $10 \mathrm{~min}$ and dabbed dry on sterile filter paper. They were then centrifuged in a syringe barrel for $15 \mathrm{~min}$ at $1,500 \mathrm{~g}$. The liquid collected was apoplastic fluid. Oxidation of syringaldazine was detected in reaction mixture containing $5 \mathrm{mM}$ Tris- $\mathrm{Cl}, \mathrm{pH} 7.5,20 \mu \mathrm{M}$ syringaldazine, $0.03 \% \mathrm{H}_{2} \mathrm{O}_{2}$ and $0.5 \%$ of apoplastic fluid. The increase in absorbance was measured at $430 \mathrm{~nm}$ for 30 seconds.

\section{Lignin Determination}

According to the method from Weiting et al. [36] stem material was ground in liquid nitrogen subjected to extraction with methanol five times over a two day period, before drying the insoluble residue at $60^{\circ} \mathrm{C}$ overnight. $100 \mathrm{mg}$ samples of this were incubated in $5 \mathrm{ml} \mathrm{10 \%}$ thioglycolic acid in $2 \mathrm{~N} \mathrm{HCl}$ at $95^{\circ} \mathrm{C}$ for $4 \mathrm{~h}$. The pellet was washed in $5 \mathrm{ml}$ water, resuspended in $5 \mathrm{ml} 0.5 \mathrm{M} \mathrm{NaOH}$ and incubated overnight at $4^{\circ} \mathrm{C}$, before centrifugation and washing with $2 \mathrm{ml}$. water. The $\mathrm{NaOH}$ extract and pellet washings were combined and $1 \mathrm{ml}$ concentrated $\mathrm{HCl}$ was added to re-precipitate the ligninthioglycolic acid (LTGA) complex. The solution was kept at $4^{\circ} \mathrm{C}$ for 2 days to aid precipitation of the LTGA complex. The precipitate was collected by centrifugation, resuspended in $2 \mathrm{ml} 0.1 \mathrm{M} \mathrm{HCl}$ and left at $4^{\circ} \mathrm{C}$ overnight. The precipitate was collected by centrifugation at $1,500 \mathrm{~g}$ for $10 \mathrm{~min}$ and then dissolved in $1 \mathrm{ml}$ of $0.5 \mathrm{M} \mathrm{NaOH}$ at $25^{\circ} \mathrm{C}$ for 24 hours. A further spin at 1,500 $\mathrm{g}$ for $3 \mathrm{~min}$ removed the insoluble material and the absorbance was then measured at $280 \mathrm{~nm}$. The concentration of lignin was calculated from a standard curve $(0-100 \mu \mathrm{g})$ prepared using commercial alkali lignin.

\section{Xylem Staining}

Hand cut stem sections were stained with phloroglucinol (5\% phloroglucinol in $78 \%$ ethanol). A drop of phloroglucinol solution was added to the section, left for 4 min and then followed by a drop of concentrated $\mathrm{HCl}$. Lignin stained pink and sections were examined under a Leitz microscope equipped with a $16 x$ lens on.

\section{Induction and Measurement of Cell Death}

Suspension cultures, seven days after subculture were spun at $250 \mathrm{~g}$ for $5 \mathrm{~min}$ to pellet the cells. The spent medium was replaced with hormone-free fresh medium before subjecting the cells to $20 \mathrm{~min}$ heat shock at temperatures between $25^{\circ} \mathrm{C}$ and $85^{\circ} \mathrm{C}$. After returning to $25^{\circ} \mathrm{C}$ and shaking for 24 hours, equal volumes of cells and fluorescein diacetate (FDA; a $0.1 \% \mathrm{w} / \mathrm{v}$ stock diluted 1:50 with culture medium), were placed on a microscope slide for examination of epifluorescence. Single cells and cells in clusters of $<6$ were scored for fluorescence. Cells that did not stain with FDA were scored as dead and those in which cytoplasm had condensed and shrunken were counted as having undergone PCD. This cell death morphology was previously described for Arabidopsis and carrot cells killed by a $55^{\circ} \mathrm{C}$ heat shock [37] and has since been demonstrated in tobacco cell lines [31]. Cells that swelled and lysed were scored as necrotic.

\section{RESULTS}

\section{Generation of Transgenic Plants}

Cloning of the HvPrx 8 vector construct was carried out as described in the methods [31]. The construct was transformed into Agrobacterium tumefaciens, which was then used to transform both wild type and Xan nc5 tobacco plants. Transformation was confirmed by the expression of the reporter gene $\beta$-glucuronidase (data not shown) and PCR (Fig. 1).

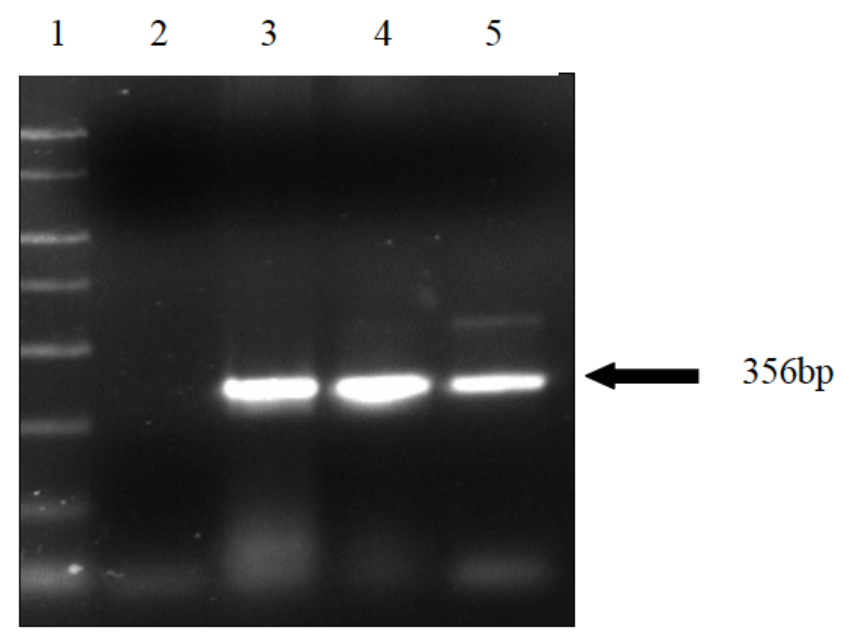

Fig. (1). PCR on tobacco plants transformed with the barley peroxidase gene, $H v P r x 8$. PCR was carried out on DNA from regenerated shoots from wild type tobacco leaf discs transformed with HvPrx 83201, to identify positive transformants. The primers $H v \operatorname{Prx} 8$ forward and $H v \operatorname{Pr} x 8$ reverse were used, resulting in a 356 bp product. Lane 1: $100 \mathrm{bp}$ ladder, lane 2: wild type tobacco, lane 3: HvPrx 83201 plasmid, lanes 3 and 4: positive transformants. 


\section{Assignment of Peroxidase Activity to Cellular Compart- ments}

Two separate lines of wild type tobacco transformed with the $H v \operatorname{Pr} x 8$ gene were studied and the results presented in (Fig. 2). Fig. (2A) displays the data from the $\mathrm{CaCl}_{2}$ extract and shows the specific activity of peroxidase, which is either freely soluble in the apoplast or ionically bound to the cell wall. Fig. (2B) shows the activity tightly bound to the cell walls, and only released by enzymatic digestion, while (Fig. 2C) represents the activity of those compartments retained by the plasmalemma (cytosolic and vacuolar). For all three fractions, there is a large increase in specific activity of peroxidase (ranging from about 5 to 8 -fold) in the two representative tobacco lines transformed with the barley peroxidase gene HvPrx 8 compared to the wild type line. The bulk of the activity in both wild-type and transformed lines is apoplastic.
A

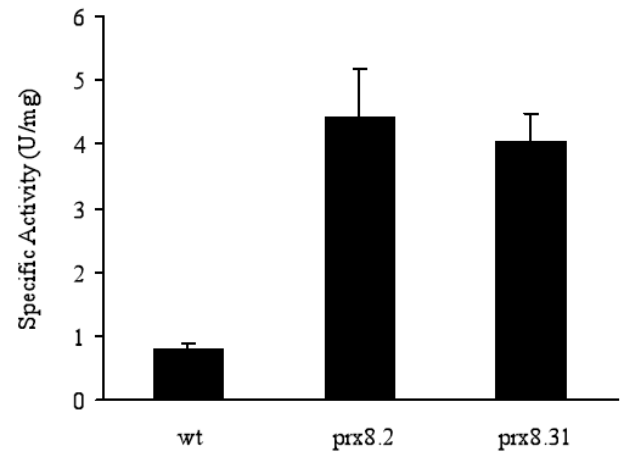

B

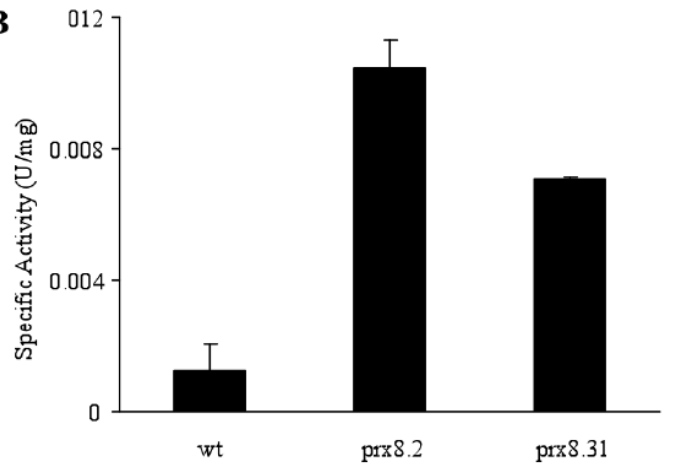

C

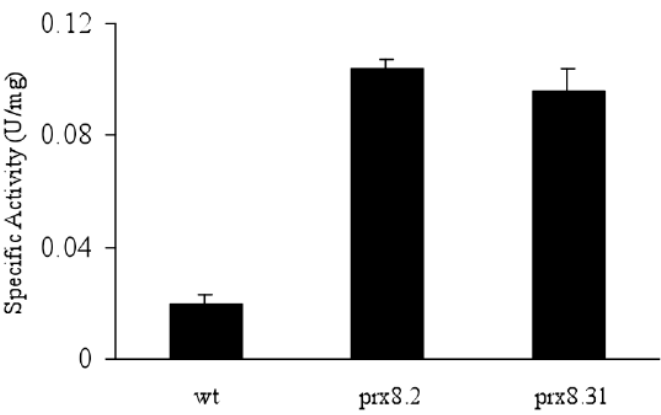

Fig. (2). Assignment of peroxidase activity to cellular compartments. The compartments were identified, and their peroxidase activities determined as described in the Materials and Methods. (A) Soluble and ionically bound apoplastic activity. Values are the means from three experiments. (B) Peroxidase activity covalently bound to the cell wall. Values are the means of four replicates. (C) The activity of those compartments retained by the plasmalemma (cytosol and vacuole). Values are the means of four replicates and the bars represent the standard errors of the mean (SEM).

\section{Induction of Ascorbate Peroxidase (APX)}

A number of tobacco transformants expressing barley peroxidase were found to have similar APX activity levels to wild type tobacco (Fig. 3). However, Xanthi nc5, the oxalate oxidase producing tobacco plants, showed elevated levels of ascorbate peroxidase activity, an effect that was greatly enhanced by the simultaneous expression of the barley peroxidase gene.

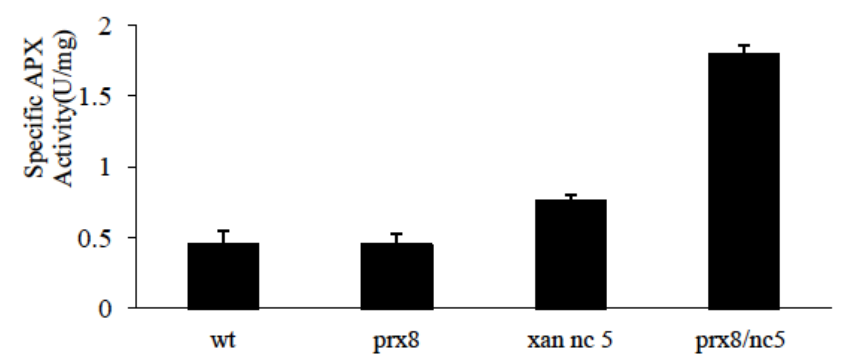

Fig. (3). Ascorbate peroxidase activity in leaf tissue of tobacco plants transformed with the barley peroxidase gene. Protein was isolated from leaf material using a buffer containing ascorbic acid as detailed in methods. The scavenging of $\mathrm{H}_{2} \mathrm{O}_{2}$ was measured and expressed as $\mu$ moles $\mathrm{H}_{2} \mathrm{O}_{2}$ consumed $/ \mathrm{min} / \mathrm{mg}$ protein (Units $/ \mathrm{mg}$ ). An extinction coefficient of $2.8 \mathrm{M} / \mathrm{cm}$ was used. Bars represent the SEM.

\section{Oxidation of Syringaldazine}

The capacity of the peroxidase present in the apoplastic fluid from two-month old tobacco plants (wild type, wt; peroxidase expressing, prx8; oxalate oxidase expressing, Xan nc5; and double transformants, prx8/nc5) to oxidise syringaldazine is illustrated in (Fig. 4). All lines exhibit a capacity to oxidise syringaldazine, but this oxidation activity is significantly enhanced in those lines transformed with $H v \operatorname{Prx} 8$ and shown to have elevated apoplastic peroxidase activity.

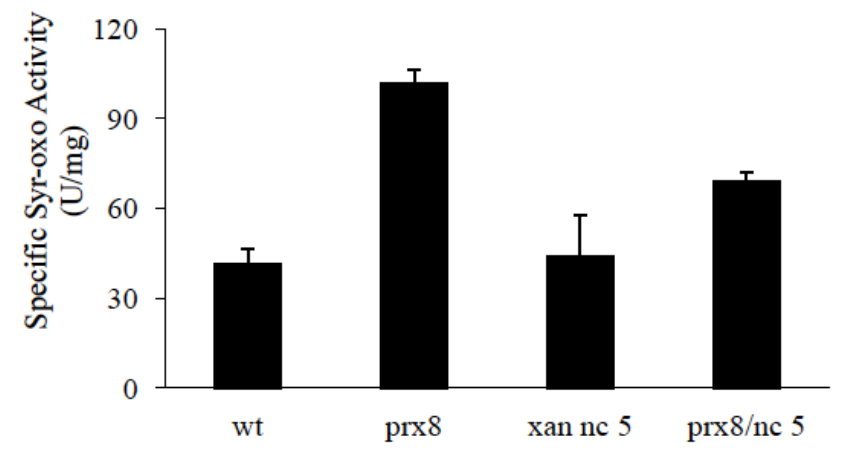

Fig. (4). Oxidation of syringaldazine by peroxidase located in apoplastic fluid. Apoplastic fluid was extracted from leaf material as described in methods and the ability of peroxidase to oxidise the lignin precursor analogue, syringaldazine was measured. Bars represent the SEM.

\section{Lignin Content and Number of Lignified Cells}

Results of lignin analysis in the different lines are illustrated in (Fig. 5). The increased apoplastic peroxidase activity, associated with expression of $H v \operatorname{Prx} 8$, was correlated with elevated extractable lignin levels in the stem, while no effect of oxalate oxidase expression could be detected. How- 
ever, examination of transverse sections from the eighth internodal stem region did reveal a concerted effect of elevated peroxidase and oxalate oxidase on formation of lignified cells in the xylem. Representative sections are illustrated in (Fig. 6). When wild type (Fig. 6A), and transgenic stems expressing barley peroxidase (Fig. 6B) are compared, the width of the xylem bands is similar but the number of lignified cells is higher in the transgenic line, as the individual cells are of smaller mean diameter. In wild type plants there was a mean of $23.25(\mathrm{SEM}=0.68)$ lignified cells across the width of the xylem band in the eighth internodal section of a four month old plant, while the equivalent value for a transgenic line was $30(\mathrm{SEM}=0.81)$. In both cases these values are the means of single counts from ten sections. Fig. (6C) illustrates a transverse stem section from tobacco expressing barley peroxidase and oxalate oxidase. The width of the band is larger and the size and density of the lignified cells resemble that of wild type plants.

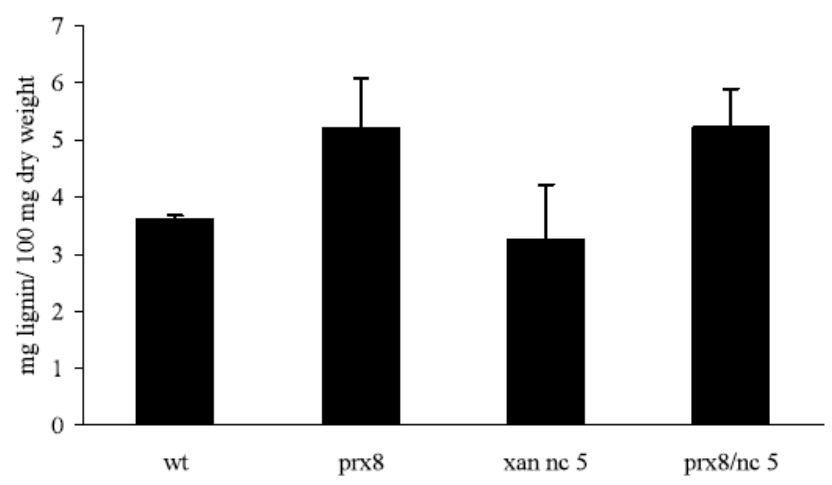

Fig. (5). Analysis of extractable lignin content in stem material of wild type and oxalate oxidase-expressing tobacco plants which were transformed with the barley peroxidase gene, $H v P r x 8$. Lignin was extracted by acidic thioglycolsis and expressed in $\mathrm{mg} / 100 \mathrm{mg}$ of dried insoluble stem material. The results were the means from at least three separate experiments using different plant material, and the bars represent the SEM.

\section{Induction of Cell Death in Cell Cultures}

Wild type, Xan nc5, HvPrx8, and doubly transformed $H v P r x 8 /$ nc5 cells were harvested 7 days after subculture and subjected to heat shock treatments, as described in Materials and Methods. Cells were scored for viability, PCD or necrosis.

The results obtained at a range of temperatures are shown in Fig. (7A). At $25^{\circ} \mathrm{C}$, a background level of cell death can be slightly increased due to centrifugation and handling of the cells. The level of PCD never rises substantially at $35^{\circ} \mathrm{C}$. At $45^{\circ} \mathrm{C}$ the cells must either commit to die or survive the treatment. Heat treatments below $55^{\circ} \mathrm{C}$, gave consistently higher PCD in the HvPrx 8 transgenic cell line, the PCD rate after $45^{\circ} \mathrm{C}$ being almost twofold higher in the peroxidase transgenic line than it is in the wild type cells and doubly transformed cell lines. From $25^{\circ} \mathrm{C}$ to $55^{\circ} \mathrm{C}$ the oxalate oxidase expressing culture was comparable to wild type tobacco cultures. At $55^{\circ} \mathrm{C}$, all cells are dead with usually at least $90 \%$ of the cells having died by PCD. At higher temperatures all the cells are dead, but the proportion that have died through $\mathrm{PCD}$, as opposed to necrosis, declines with temperature. We highlighted the $45^{\circ} \mathrm{C}$ heat treatment since at this temperature there is room for fluctuation of cell death levels. The percentage of cell death at $45^{\circ} \mathrm{C}$ remaining after the removal of background cell death levels was plotted (Fig. 7B). This figure emphasises the large increase in programmed cell death in $H v \operatorname{Prx} 8$ transgenic cell lines compared to wild type and double transformants (HvPrx8/nc5).
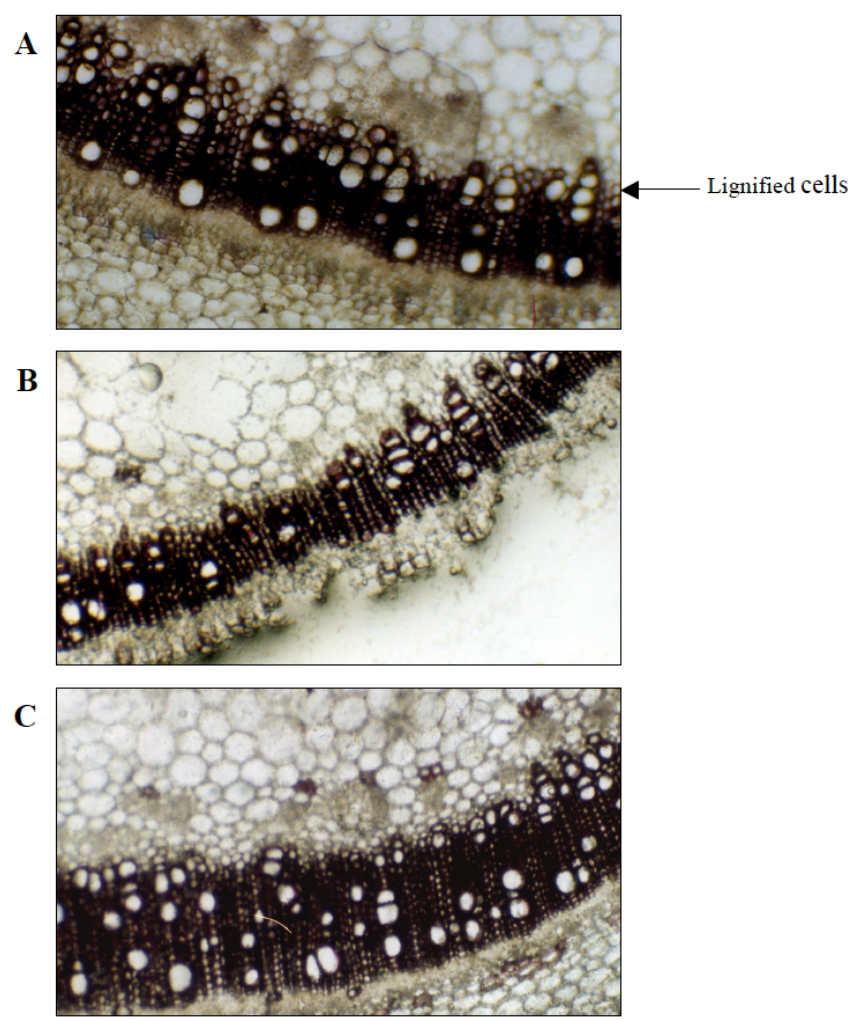

Fig. (6). Representative transverse sections from the eighth internode of wild type and transgenic plants showing the band of lignified cells. Phloroglucinol was used to stain the hand cut sections. Magnification: 160x. (A) = wild type tobacco, $(\mathbf{B})=$ tobacco transferred with barley peroxidase gene and $(\mathbf{C})=$ tobacco expressing barley peroxidase and oxalate oxidase

\section{DISCUSSION}

Subcellular localisation of peroxidase activity illustrated that the majority of activity in transgenic Nicotiana tabacum plants expressing barley peroxidase (HvPrx 8 plants) is located in the soluble and ionically bound fraction from the apoplast. Relatively little activity was found in the cytosolic/vacuolar fraction. This is in agreement with an earlier expression study in the diploid Nicotiana benthamiana which showed the barley $H v \operatorname{Pr} x 8$ is expressed in a form indistinguishable from the native in terms of intercellular localisation and posttranscriptional processing [38]. In view of the pivotal role of peroxidase in lignin synthesis, it might be anticipated that these elevated apoplastic levels could influence lignification. This surmise is supported by the increased capacity of the apoplastic fluid from the HvPrx 8 plants to oxidise a lignin precursor analogue, syringaldazine, for which cell wall peroxidases involved in lignification have a high affinity. The oxidation of syringaldazine by a peroxidase was suggested to be indicative of its involvement in the 

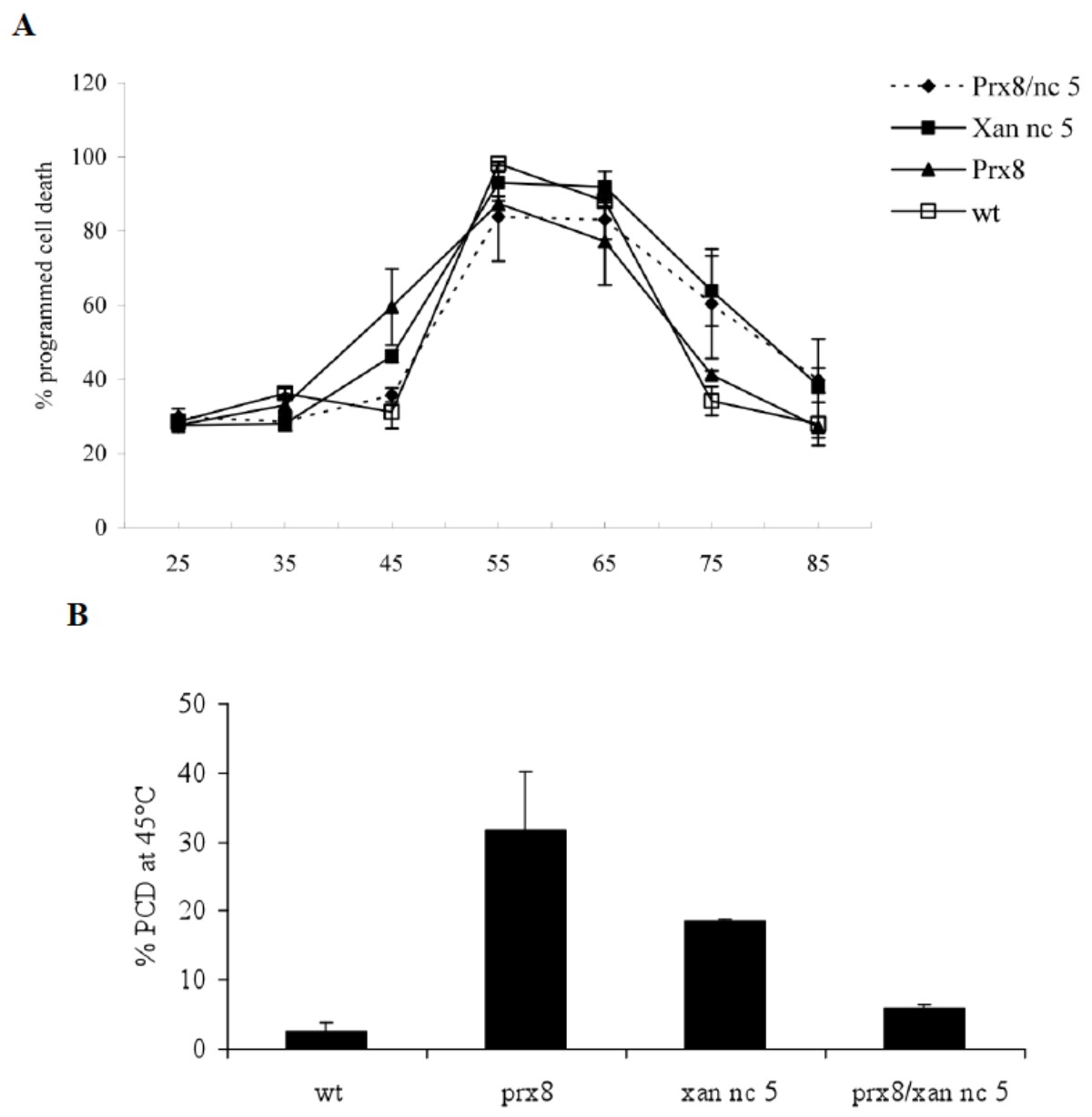

Fig. (7). The effect of peroxidase, oxalate oxidase and their combined expression on the induction of PCD. (A) Cells were subjected to heat treatments for $20 \mathrm{~min}$, returned to $25^{\circ} \mathrm{C}$ and scored 24 hours later. Cells were scored under the light microscope for PCD morphology, as described in the Materials and Methods, and the percentage of cells undergoing PCD was determined. (B) The percentage of cell death at $45^{\circ} \mathrm{C}$ remaining after the removal of background cell death levels. Data shown are representative of three independent replicate experiments. Error bars represent SEM, which is derived from independent fields of at least 100 cells for each experiment.

synthesis of lignin [39, 16]. Plants transformed with both barley peroxidase and oxalate oxidase genes (HvPrx8/nc5 plants) showed a reduction in syringaldazine oxidase activity compared to lines transformed with the barley peroxidase gene alone. We propose that this is due to reduced peroxidase activity in doubly transformed lines based on peroxidase inactivation by $\mathrm{H}_{2} \mathrm{O}_{2}$ [40].

The activity of ascorbate peroxidase has been shown to accumulate in response to stresses which result in an increase in ROS production [35]. This lends an explanation to why transgenic plants expressing oxalate oxidase (nc5 plants), a source of $\mathrm{H}_{2} \mathrm{O}_{2}$, show an increase in ascorbate peroxidase activity. Since double transformants expressing barley peroxidase and oxalate oxidase have potentially two sources of $\mathrm{H}_{2} \mathrm{O}_{2}$ [41], it was not surprising that these plants had the highest ascorbate peroxidase activity. However in the absence of $\mathrm{H}_{2} \mathrm{O}_{2}$ measurements in the present study, this interpretation must remain speculative.

Tobacco plants expressing high levels of barley peroxidase showed an increased level of extractable lignin compared to that of wild type tobacco plants. This finding is consistent with the increase in the oxidation of the lignin precur- sor analogue, syringaldazine, in the same plants. As mentioned earlier other reports have associated peroxidases present in tissues undergoing lignification with in vitro activity towards syringaldazine $[42,16]$. Therefore, we suggest that the apoplastic barley peroxidase in these transgenic tobacco plants was active at sites of lignification. The width of the xylem band in both plants was similar but it was observed that the xylem band of the HvPrx8 plants consisted of a greater number of smaller lignified cells. Increased lignification can decrease cell wall plasticity and consequently there could be reduction in cell expansion. A difference in xylem band width was observed in the transgenic line expressing both peroxidase and oxalate oxidase. The band is much wider in HvPrx8/nc5 plants, compared to either wild type or barley peroxidase tobacco and an increased level of lignin was found in this double transgenic line compared to wild type or oxalate oxidase tobacco, although the level was similar to that of $H v \operatorname{Prx} 8$ plants. It is proposed that the additional expression of oxalate oxidase, a possible source of $\mathrm{H}_{2} \mathrm{O}_{2}$, could also effect lignification. However, there was no direct evidence produced from lignin level measurements that expression of oxalate oxidase alone could lead to the modification of lignin content. 
We investigated the effect that elevated levels of peroxidase may have on the induction of programmed cell death in plant cells. We utilised cell morphology to measure rates of cell death after heat shocks [37] and could observe the influence of the introduced peroxidase gene on these rates. At $45^{\circ} \mathrm{C}$, large differences in PCD levels were observed while at $55^{\circ} \mathrm{C}$ the majority of cells died regardless of the deathinducing agent. In cell cultures expressing barley peroxidase only, there was a substantial increase in $\mathrm{PCD}$ at $45^{\circ} \mathrm{C}$, a finding consistent with our earlier observations [31]. Although $\mathrm{H}_{2} \mathrm{O}_{2}$ is a known activator of PCD [43-46] direct measurement of $\mathrm{H}_{2} \mathrm{O}_{2}$ levels would be needed to confirm that changes in those levels are responsible for the altered PCD response in the transgenic plants.

To summarise, studies on tobacco plants with enhanced levels of apoplastic peroxidase suggest that modest increases in peroxidase activity can influence cell wall-related processes such as the peroxidase-dependent phenomenon of lignification. Furthermore, this effect can be influenced by the simultaneous expression of a known $\mathrm{H}_{2} \mathrm{O}_{2}$-generating enzyme, oxalate oxidase.

\section{ABBREVIATIONS}

$\begin{array}{ll}\text { APX } & =\text { Ascorbate peroxidase } \\ \text { Class III } & =\text { Peroxidase } \\ \text { ROS } & =\text { Reactive oxygen species } \\ \text { PCD } & =\text { Programmed cell death }\end{array}$

\section{CONFLICT OF INTEREST}

The authors confirm that this article content has no conflict of interest.

\section{ACKNOWLEDGEMENTS}

The authors gratefully acknowledge the financial support of Enterprise Ireland (grant: SC/97/104).

\section{REFERENCES}

[1] Amor Y, Chevion M, Levine A. Anoxia pre-treatment protects soybean against $\mathrm{H}_{2} \mathrm{O}_{2}$ - induced cell death: possible involvement of peroxidases and of alternative oxidase. FEBS Lett 2000; 477: 17580 .

[2] Bestwick CS, Brown IR, Mansfield JW. Localised changes in peroxidase activity accompany hydrogen peroxide generation during the development of a nonhost hypersensitive reaction in lettuce. Plant Physiol 1998; 118: 1067-78.

[3] Jansen MAK, van den Noort RE, Adillah MY, Prinsen E, Lagrimini LM, Thorneley RNF. Phenol-oxidizing peroxidases contribute to the protection of plants from ultraviolet radiation stress. Plant Physiol 2001; 126: 1012-23.

[4] Siegel BZ. Plant peroxidises - an organismic perspective. Plant Growth Reg 1993; 12: 303-12.

[5] Beffa R, Martin H, Pilet PE. In vitro oxidation of indoleacetic acid by soluble auxin-oxidases and peroxidases from maize roots. Plant Physiol 1990; 94: 485-91.

[6] Mensen R, Hager A, Salzer P. Elicitor-induced changes of wallbound and secreted peroxidase activities in suspension-cultured spruce cells are attenuated by auxins. Physiol Plant 1998; 102: 53946.

[7] Kristensen BK, Bloch H, Rasmussen SK. Barley coleoptile peroxidases. Purification, molecular cloning and induction by pathogens. Plant Physiol 1999; 120: 501-12.
[8] Quiroga M, Guerrero C, Botella MA, et al. A tomato peroxidase involved in the synthesis of lignin and suberin. Plant Physiol 2000; 122: 1119-27.

[9] Lagrimini LM, Gingas V, Finger F, Rothstein S, Ting-Ting YL. Characterization of antisense transformed plants deficient in the tobacco anionic peroxidase. Plant Physiol 1997; 114: 1187-96.

[10] Lagrimini LM, Bradford S, Rothstein S. Peroxidase induced wilting in transgenic tobacco plants. Plant Cell 1990; 2: 7-18.

[11] Vicuna D, Malone RP, Dix PJ. Increased tolerance to abiotic stresses in tobacco plants expressing a barley cell wall peroxidase. J Plant Sci 2011; 6: 1-13.

[12] Welinder KG, Justesen AF, Kjærsgaard IVH, et al. Structural diversity and transcription of 40 peroxidases from Arabidopsis thaliana. Eur J Biochem 2002; 269: 6063-81.

[13] Holm KB, Andreasen PH, Eckloff R, Kristensen BK, Rasmussen SK. Lignin related peroxidases from Asparagus officinalis. J Exp Bot 2003; 54: 2275-84.

[14] Mader M, Amberg-Fisher V. Role of peroxidase in lignification of tobacco cells. Plant Physiol 1982; 70: 1128-31.

[15] Ros Barcelo A, Pedreno A, Munoz R, Sabater F. Physiological significance of the binding of acidic isoperoxidases to cell walls of lupin. Physiol Plant 1989; 75: 267-74.

[16] Christensen JH, Bauw G, Welinder KG, Van Montagu M, Boerjan W. Purification and characterisation of peroxidases correlated with lignification in poplar xylem. Plant Physiol 1998; 118: 125-35.

[17] Thordal-Christensen H, Brandt J, Cho BH, et al. cDNA cloning and characterisation of two barley peroxidase transcripts induced differentially by the powdery mildew fungus Erysiphe graminis. Physiol Mol Plant Pathol 1992; 40: 395-409.

Berna A, Bernier F. Regulated expression of a wheat germin gene in tobacco: oxalate oxidase activity and apoplastic localization of the heterologous protein. Plant Mol Biol 1997; 33: 417-29.

Berna A, Bernier F. Regulation by biotic and abiotic stress of a wheat germin gene encoding oxalate oxidase, a $\mathrm{H}_{2} \mathrm{O}_{2}$-producing enzyme. Plant Mol Biol 1999; 39: 539-49.

Hurkman W, Tao HP, Tanaka CK. Germin-like polypeptides increase in barley roots during salt stress. Plant Physiol 1991; 97: 366-74.

[21] Dumas B, Freyssinet G, Pallett KE. Tissue-specific expression of germin-like oxalate oxidase during development and fungal infection of barley seedlings. Plant Physiol 1995; 107: 1091-6.

[22] Zhang Z, Collinge D, Thordal-Christensen H. Germin-like oxalate oxidase, a $\mathrm{H}_{2} \mathrm{O}_{2}$-producing enzyme, accumulates in barley attacked by the powdery mildew fungus. Plant J 1995; 8: 139-45.

[23] Bestwick CS, Adam AL, Puir N, Mansfield JW. Characterisation of and changes to pro- and anti-oxidant enzyme activities during the hypersensitive reaction in lettuce. Plant Sci 2001; 161: 497-506.

[24] Morita S, Kaminaka H, Masumura T, Tanaka K. Induction of rice cytosolic ascorbate peroxidase mRNA by oxidative stress: the involvement of hydrogen peroxide in oxidative stress signalling. Plant Cell Physiol 1999; 40: 417-22.

[25] Noctor G, Foyer CH. Ascorbate and glutathione: keeping active oxygen under control. Annu Rev Plant Physiol Plant Mol Biol 1998; 49: 249-79.

[26] Poage M, Le Martret B, Jansen MAK, Nugent GD, Dix PJ. Modification of reactive oxygen species (ROS) scavenging capacity of chloroplasts through plastid transformation. Plant Mol Biol 2011; 76: 371-84

[27] Le Martret B, Poage M, Shiel K, Nugent GD, Dix PJ. Tobacco chloroplast transformants expressing genes encoding dehydroascorbate reductase, glutathione reductase, and glutathione-Stransferase, exhibit altered anti-oxidant metabolism and improved abiotic stress tolerance. Plant Biotechnol J 2011; 9: 661-73.

[28] Fukuda H. Xylogenesis: initiation, progression and cell death. Annu Rev Plant Physiol Plant Mol Biol 1996; 47: 299-325.

[29] Mittler R, Lam E, Shulaev V, Cohen M. Signals controlling the expression of cytosolic ascorbate peroxidase during pathogen induced programmed cell death in tobacco. Plant Mol Biol 1999; 39: 1025-35.

[30] McCabe PF, Levine A, Meijer PJ, Tapon NA, Pennell RI. A programmed cell death pathway activated in carrot cells cultured at low cell density. Plant J 1997; 12: 267-80.

[31] Burbridge E, Diamond M, Dix PJ, McCabe PF. Use of cell morphology to evaluate the effect of a peroxidase gene on cell death induction thresholds in tobacco. Plant Sci 2006; 171: 139-146. 
[32] Murashige T, Skoog F. A revised medium for rapid growth and bioassays with tobacco tissue cultures. Physiol Plant 1962; 15: 47397.

[33] Bradford MM. A rapid and sensitive method for the quantification of microgram quantities of protein utilizing the principle of proteindye binding. Anal Biochem 1976; 72: 248-54.

[34] McDougall GJ. Cell-wall-associated peroxidase and lignification during growth of flax fibres. J Plant Physiol 1991; 139: 182-6.

[35] Asada K. Ascorbate peroxidase- a hydrogen peroxide scavenging enzyme in plant. Physiol Plant 1992; 85: 235-241.

[36] Weiting NI, Paiva NI, Dixon RA. Reduced lignin in transgenic plants containing a caffeic acid $O$-methyltransferase antisense gene. Transgenic Res 1994; 3: 120-6.

[37] McCabe PF, Leaver CJ. Programmed cell death in cell cultures. Plant Mol Biol 2000; 44: 359-68.

[38] Kristensen BK, Brandt J, Bojsen K, et al. Expression of a defencerelated intercellular barley peroxidase in transgenic tobacco. Plant Sci 1997; 122: 173-82.

[39] Pang A, Catesson AM, Francesch C, Rolando C, Goldberg R. On substrate specificity of peroxidases involved in the lignification process. J Plant Physiol 1989; 135: 325-9.

[40] Hernandez-Ruiz J, Rodriguez-Lopez JN, Garcia-Canovas F, Acosta $\mathrm{M}$, Arnao MB. Characterisation of isoperoxidase-B2 inactivation in etiolated Lupinus albus hypocotyls. Biochim Biophys Acta 2000; 1478: 78-88.

[41] McLusky SR, Bennett MH, Beale MH, Lewis MJ, Gaskin P, Mansfield JW. Cell wall alterations and localised accumulation of feruloyl-3' -methoxytyramine in onion epidermis at sites of attempted penetration by Botryis allii are associated with actin polarisation, peroxidase activity and suppression of flavonoid biosynthesis. Plant J 1999; 17: 523-34.

[42] Goldberg R, Catesson AM, Czaninski Y. Some properties of syringaldazine oxidase, a peroxidase specifically involved in the lignification process. J Plant Physiol 1983; 110: 267-79.

[43] Desikan R, Reynolds A, Hancock JT, Neill SJ. Harpin and hydrogen peroxide both initiate programmed cell death but have differential effects on defence gene expression in Arabidopsis suspension cultures. Biochem J 1998; 330: 115-20.

[44] Panavas T, Rubinstein B. Oxidative events during programmed cell death of daylily petals. Plant Sci 1998; 133: 125-38.

[45] Grant JJ, Loake GJ. Role of reactive oxygen intermediates and cognate redox signalling in disease resistance. Plant Physiol 2000; 124: 21-9.

[46] Bethke PC, Jones RL. Cell death of barley aleurone protoplasts is mediated by reactive oxygen species. Plant J 2001; 25: 19-29.

(C) Burbridge et al.; Licensee Bentham Open.

This is an open access article licensed under the terms of the Creative Commons Attribution Non-Commercial License (http://creativecommons.org/licenses/by-nc/3.0/) which permits unrestricted, non-commercial use, distribution and reproduction in any medium, provided the work is properly cited. 